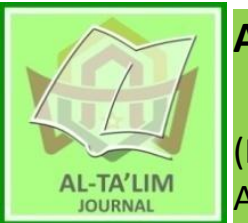

AL-TA'LIM JOURNAL, 26 (1), 2019, (23-37)

(Print ISSN 1410-7546 Online ISSN 2355-7893)

Available online at http://journal.tarbiyahiainib.ac.id/index.php/attalim

\title{
English Skills Based Microteaching: An Effective Model in Enhancing English Student Teachers' Teaching Skills
}

Received: $08^{\text {th }}$ January 2019; Revised: $22^{\text {th }}$ January 2019; Accepted: $28^{\text {th }}$ February 2018

Permalink/DOI: http://dx.doi.org/10.15548/jt.v26i1.556

\section{Darmayenti *) \\ Universitas Negeri Imam Bonjol \\ Padang, Indonesia. \\ E-mail: darmayenti@uinib.ac.id}

\section{Besral \\ Universitas Negeri Imam Bonjol Padang, Indonesia. \\ E-mail: besralod@gmail.com}

\section{Martin Kustati}

Universitas Negeri Imam Bonjol

Padang, Indonesia.

E-mail: martinkustati@yahoo.com

\section{*) Corresponding Author}

\begin{abstract}
Building basic teaching and English skills for student teachers need appropriate and effective teaching model. The current study aimed at designing a model of Micro-teaching Based-English Skill for undergraduates English program at State Islamic University. Research and Development type was used to develop the model. The subjects of this study were seven groups of students (each consist of 12 students) and seven lecturers. Two groups were cluster randomly selected participate in this study. Pre-test and posttest design of experimental research model has been used without the control group and followed by treatment for 8 weeks prior to their teaching practice in the nearby schools. Data were taken from observations, questionnaires, and test. The results showed that Micro-teaching Based-English Skill model was appropriate for the lecturers and students. The students' basic teaching and their English skills were better improved. Therefore, this model is suggested to be implemented provided that both English skills and pedagogical one were the major expectation to be reached.
\end{abstract}

Keywords: Teaching model; micro-teaching; basic teaching skills; skills in teaching English

How to cite: Darmayenti, D., Besral, B., \& Kustati, M. (2019). English Skills Based Microteaching: An Effective Model in Enhancing English Student Teachers' Teaching Skills. Al-Ta Lim Journal, 26(1). doi:http://dx.doi.org/10.15548/jt.v26i1.556

\section{INTRODUCTION}

One of the most important factors in improving the quality of education and the teaching process is the teachers. Therefore, it is very important to train teachers who can compete with the rapidly developing age. From the traditional perspective, the teacher is the source and transmitter of knowledge; however, nowadays s/he has become the guide of the students throughout the learning process. This new role requires the teachers of today to attain new competencies, which creates an obligation to review and revise the teacher education programmes (Klinzing \& Folden, 1991; Liston, Whitcomb, \& Borko, 2006). One of the most salient efforts to realize this purpose is by modifying the learning process that provides the students with bigger responsibility, trains them to get accessed of information, facilitating them to work in pair or peers, providing the opportunity for the students to perform idea or thought, as well as to provide sense of happiness. To achieve that purpose, then, a teacher as educator has to be able to create meaningful, creative, fun and dialogical learning atmospheres (Education Law No 20 of Year 2003 and National Regulation No 19 of Year 2005).

The realization of the above ideas may be processed through Micro-Teaching program, a form of learning that prepares student teachers to become educator prior to their teaching practicum. Microteaching is a 
teacher training technique for learning teaching skills. It employs real teaching situation for developing pedagogical content, knowledge of student-teachers and helps them to get adequate knowledge regarding the art of teaching. The instructional process of Micro-Teaching is simple but tightly controlled activities, attended by limited number of students (3-10 students) within limited time (5-20 minutes) (Allen, 1996; Chen, 2010). In Micro teaching, studentteachers are trained with several teaching skills whereas supervisor act as facilitator to inform the rules of Micro teaching; guide the student teacher in preparing lesson plan; guide students in the simulation or limited teaching; and to observe the simulation thoroughly (Mulyasa, 2003). Unlike inservice training that serves as a bridge between prospective and experienced educators to meet the new challenges of guiding students towards higher standards of learning and self development, micro teaching functions as a form of learning that prepares university student teachers to become educator prior to their field practice of teaching in schools The expected results have been to form knowledge of teaching and learning process, basic and specific teaching skills, as well as attitudes and behavior suit to ideal teacher (Anson, 2003; Mulyasa, 2003; Bell, 2007).

Microteaching is an integral part of any teacher education curriculum since it is a good avenue for pre-service teachers to apply the theories they learned in the real classroom setting. Although practice teaching in education is still a challenge because it does not fully prepare student teachers for the actual classroom teaching, Starkey and Rawlins (2012) mentioned that these student teachers should be well-monitored, supervised, and guided by their supervising teacher through online discussion and classroom teaching observation for them to become prepared. Through constant monitoring and guidance from the teacher educators, these student-teachers will learn how to handle and manage not just their daily lessons but the students and their classroom as well. Because of this, Tuli and File (2009) described microteaching experience among pre-service teachers as the most important part of teacher education program.

In Indonesia, especially in the faculty of Teacher Training, Microteaching is offered to the sixth semester students, those who have completed some minimal requirements such as having satisfying results or competences in teaching and learning subjects including classroom management, administration, use of learning aids or media, methods of teaching, classroom techniques, EFL curriculum and textbook, EFL technique of evaluation, etc. Twelve to fifteen students may apply for a class of Microteaching that will be handled by a senior instructor relevant to the students' field or department. Each classroom is provided with an $\mathrm{LD} /$ in-Focus and students are supposed to bring other relevant media based on agreed schedules.

A number of studies emphasized the nature and importance of practicum or microteaching. For example, Nunan (2009) when giving an overview of the classroom practices in teaching said that classroom informed by current views on language pedagogy will involve a change in teaching approach away from a high structure orientation towards a more low-structure orientation. Meanwhile, Pinder and McDonald (2006) noted that if students were active on the actual practice teaching experience and with the constant guidance from their associate teachers, they would learn the art of teaching.

Micro Teaching program is believed to improve student teachers' competence in teaching in the real class or classroom settings (Natalia, 2013; Oktavia, 2014; Najjah, 2014). It will also improve their efficacy (Mergler and Tangen, 2010). It facilitates enhancement of student teachers' understanding of reformoriented teaching and knowledge of subject matter through collaboration with peers and feedback from an instructor (Fernadez, 2005). It is a proven method to attain gross improvement in the instructional experiences ( Singh, 1987; Allen, 1996; Cruickshank, 1996; Chen, 2010; Ismail \& Saddik, 2011 ). Microteaching also increases the self- 
confidence, improves the in-class teaching performances, and develops the classroom management skills instructor (Deniz, 2011). However, there has been no evident to show that it might also develop some teaching skills for every language skills in English such as listening, speaking, reading, and writing ((Darmayenti \& Besral, 2017). As evidenced from previous years of field practice, most participants failed to demonstrate their fluent English to the school students. Sequence of learning was not properly implemented. Consequently, most of their teaching and learning objectives were not achieved. Global competition and changes in school curriculum as well as in Higher Education are among the factors that necessitate the development of learning model for Microteaching so that student teachers are assisted in teaching English skills. Therefore, the need to fill this gap should be initiated by modifying the learning process that provides the students with bigger responsibility. Instructors or advisors should train them to get accessed of information, work in pair or peers, provide the opportunity for the students to perform idea or thought, achieve learning goals, as well as to provide sense of happiness. To achieve this purpose, then, a teacher as educator has to be able to create meaningful, creative, fun and dialogical learning atmospheres (National Constitution on National Education System No 20 Year 2003, Article 40, National Regulation 19 Year 2005, and Article 19).

Through Micro teaching, a candidate teacher is trained with several teaching skills whereas supervisor act as facilitator; guide the student teacher in preparing lesson plan; guide students in the simulation or limited teaching; and observe the simulation thoroughly (Mulyasa, 2003). This is in accordance with National Regulation No 49 Year 2014 that learning must be interactive, holistic, integrative, scientific, contextual, thematic, effective, collaborative, and students centered. It is expected that through this way, students will be able to develop their competences either in cognitive, affective, or skills and higher education goals namely to enable students to become knowledgeable person, smart, creative, self-sufficient, skillful, and civilized. This is in line with Fellow \& Liu (2015) that a model should: be oriented to student teachers' need; be based competence, be based on system approach, and be empirically tested.

In an attempt to achieve the desired goals as stated above, the current study seeks to uncover the following questions: 1.what is the appropriate model of Microteaching Based English Skills for Undergraduate English Program? 2. What is the effect of the model toward students' basic English skills; 3. What is the effect of the model toward students' basic teaching skills? 4 . What is the most dominant basic English skills that is improved through this model? Based on the questions stated above, the current study was directed to design Micro-Teaching Based English Skills in order to help both student teachers and instructors in developing their teaching skills. The analysis of students' classroom practices and interviews were expected to enable the researchers to sequence or modify the model being developed and to look for its effectiveness as well as its strengths in the perspective of language skill or competence.

Concepts of planning in preparation of good and qualified teachers have long been promoted across the countries for many decades and yet, satisfactory results seemed to be far due to fast and over changing view of the world as well as cultural values that shaped people from generation to generation. Practitioners in the field of education coined such efforts with various terms such as 'microteaching' Anson (2003) 'in service training' Omar (2014) 'in service education' Osamwony (2016), and 'practicum teaching' Ulla (2016) to refer to a specific program that upgrades knowledge, skills, and competence in the teaching profession.

Microteaching is a teacher training technique for learning teaching skills. The idea of microteaching is first developed by Dwight W. Allen in 1963. It is a teacher training technique whereby the teacher reviews a recording of a teaching session, in order to get constructive feedback from peers 
and/or students about what has worked and what improvements can be made to their teaching technique (Allen, 1996; Bell,2008). It employs real teaching situation for developing pedagogical content, knowledge of student-teachers and helps them to get adequate knowledge regarding the art of teaching. The instructional process of MicroTeaching is simple but tightly controlled activities, attended by limited number of students (3-10 students) within limited time (5-20 minutes) (Paintal, 1980; Allen, 1996; Bell,2008; Chen, 2010). It scales down the complexities of real teaching, as immediate feedback can be sought after each practice session (Paintal, 1980; Anson, 2003; Bell, 2008). Multimedia equipment such as audiovideo recording devices have a key role in the learning process (MacLeod, 1995).

Micro-teaching is mainly on the practice of teaching in which a number of learners are involved. This may be live demonstration, or a video presentation of the skill. Then, the group members select a topic and prepare a lesson of 10-15 minutes. The student teacher then has the opportunity to practice and evaluate his/her use of the skills. Practice takes the form of a 10-to-15-minute micro-teaching session in which 10 to 15 student teachers are involved. The expected results have been to form knowledge of teaching and learning process, basic and specific teaching skills, as well as attitudes and behavior suit to ideal teacher (Anson, 2003; Mulyasa, 2003; Bell, 2007).

In Micro teaching, student-teachers are trained with several teaching skills whereas supervisor act as facilitator to inform the rules of Micro teaching; guide the student teacher in preparing lesson plan; guide students in the simulation or limited teaching; demonstrate the certain teaching skill to be practiced and to observe the simulation thoroughly (Mulyasa, 2003). In line with this idea, Microteaching has proved to attain gross improvement in the instructional experience ( Singh, 1987; Allen, 1996; Cruickshank, 1996; Chen, 2010). In addition, Microteaching helps in eliminating errors and builds stronger teaching skills for the student teachers (
Ananthakrishnan, 1993; Roush,2008). Microteaching increases the self-confidence, improves the in-class teaching performances, and develops the classroom management skills ( Denis, 2011; Deon, 2011).

English Skills Based Micro-Teaching model is a model where the student teachers practice teaching each English component skills with the appropriate teaching techniques. Designing model of English Skills Based Micro-Teaching model is in line with Ministry of Research and Technology of Higher Education Regulation Number 44 Year 2015 about National Standard of Higher Education article 10 and 11 stating that standard of learning in higher education constituted minimal criterion about teaching and learning process at a study program to achieve the outcomes under the following characteristics: interactive, holistic, integrative, scientific, collaborative, and students centered. Interactive means the interaction of two directions between students and instructor. Holistic is forming comprehensive and wide pattern of thought by internalizing virtue, local and national wisdom. Integrative is holistic in a united program through inter-discipliners and multidiscipliners. Scientific relies on scientific approach. Collaborative involves interactions between learners to produce strong attitudes, knowledge, and skills. And students centered means learning model should give opportunity for the students to create fun learning and directs them to individual learning. Above all, this design was originated from previous model ever done by the instructors.

This learning model design was structured in such a way that it followed the following steps: First, determining learning preparation which is arranged into Semester Lesson Plan. Second, determining teaching steps may be used by instructor. The Implementation phase of model was being organized in such a way that the event was started with the opening of the activities by instructors. Implementation must be ensured that the participants were ready to learn. Giving motivation in learning and explaining 
each meeting learning objectives were very important. The learning process should be explained in detail to participants included theory and activities. Before coming to the teaching practice, the students should be prepared by some knowledge of teaching. Knowledge acquisition phase is the preparatory, pre-active phase, in which the teacher gets trained on the skills and components of teaching through lectures, discussion, illustration, and demonstration of the skill by the experts.

Activities in Microteaching consists of three main steps namely pre teaching activity, main teaching activity, and post teaching activity. First, at the beginning of teaching activity, there was a preparation including preparing the learning process, arranging the students' seat, and display the sample of lesson plan. There are some activities carried out, namely, take attendance, build participants' attention, motivate participants and, greet them, provide guidance learning, and give them pre test. Second, the main activities were carried out by the communicative learning techniques. The teacher plans a micro-lesson for practicing the demonstrated skills. The colleagues and peers can act as constructive evaluators which also enable them to modify their own teachingearning practices. Learning process should give full learning opportunity to participants. There are some activities conducted namely, orientation, including introduction the material of teaching; exploration including modeling of teaching skills; and elaboration activities including skill practice, practice teaching, video tape recording, giving feed back; and for re-creation, teaching creation by the students. Ultimately, they can integrate and transfer this learned skills from simulated teaching situation to real class room teaching. The last activities are conclusion and reflection. Third, on the post activity, the instructor lecturer gives feedback of the learning process. Evaluation phase microteaching model is activity to determine whether the participants get improvement or not after giving the learning. There were two stages of the evaluation activities. First, the evaluation process was through teaching test.
Second, the activity was obtaining the participants 'opinions by filling a questionnaire sheet to the student teachers. Model of Micro teaching Based English skills in developing student teachers at English Department of State Islamic University can be recommended to English lecturers.

\section{METHOD}

This study was a research and development type (R\&D) and was aimed at designing model of Micro-Teaching Based English Skills for the student teachers at English Department, State Islamic University Imam Bonjol of Padang. By following Gall, Gall, and Borg's model (2003), there were steps in designing the model namely determining the purpose of designing a model, gathering information through reading the literature, observing the activities of lecturers in developing students teachers' skills in teaching, and analyzing the needs of the development of English students' skills; designing draft of a development model; validating the model and revision; implementing the model; and evaluating the model. The new model was discussed with the experts through focus group discussion (FGD). Video camera and evaluation forms on basic teaching and English skill which proposed by Harmer and Asril (2010; 2003) were used to collect the data. Twenty two active students at English Department of Islamic Studies in Padang in Academic Year 2017/2018, who were cluster randomly selected, and seven lecturers participate in this study (Sugiyono, 2010:120). The data of this research were student teachers' skills on English and basic teaching achievement. Observation was used to search and collect all information from the lecturers and the students in learning Microteaching subject. Questionnaire and interview were used to support the data collected. Test, observation, and interview were used to collect data. Pretest and post-test design of experimental research model has been used without the control group and followed by treatment for 8 weeks. Basic teaching and English teaching skills were given to the students. Qualitative 
analysis was used to describe the result of implementation Micro-Teaching Based English Skills for the student teachers. Quantitative analysis was used to describe the effect model in improving student' teachers teaching skills and analyze the gain score groups by using t-test. All the data were input into the computer, and they were analyzed through the Statistical Package for Social Science (SPSS17.0). To be more specific, firstly, descriptive statistics such as frequencies means, and standard deviations were computed.

\section{RESULTS AND DISCUSSION}

\section{Model of English Skill Based Micro- Teaching Model}

Designing model of Micro teaching Based English skills was in line with Ministry of Research and Technology of Higher Education Regulation Number 44 Year 2015 about National Standard of Higher Education article 10 and 11 stating that standard of learning in higher education constituted minimal criterion about teaching and learning process at a study program to achieve the outcomes under the following characteristics: interactive; namely the interaction of two directions between students and instructor; holistic, forming comprehensive and wide pattern of thought by internalizing virtue, local and national wisdom; integrative, that is holistic in a united program through interdiscipliners and multi-discipliners; scientific; relies on scientific approach; collaborative, involving interactions between learners to produce strong attitudes, knowledge, and skills; students centered. Learning model should give opportunity for the students to create fun learning and directs them to individual learning. Above all, this design was originated from previous model ever done by the instructors.

This learning model design was structured in such a way that it followed the following steps namely determining learning preparation which is arranged into Semester Learning Plan and determining teaching steps to be used by instructor. The Implementation phase of model was being organized in such a way that the event was started with the opening of the activities by instructors. Implementation must be ensured that the participants were ready to learn. Giving motivation in learning and explaining each meeting learning objectives were very important.

The learning process should be explained in detail to participants included theory and activities. Activities in Microteaching consists of three main steps namely pre teaching activity, main teaching activity, and post teaching activity. First, at the beginning of teaching activity, preparations must be made in terms of arranging the students' seat, and displaying the sample of lesson plan. Participants should know how to take attendance, build participants' attention, motivate participants and, greet them provide guidance learning, give pre test. Second, the main activities were carried out by the communicative learning techniques. Learning process should give full learning opportunity to participants. For the main teaching activities, participants are required to do the following things like: orientation, including introduction to the material of teaching; exploration, including modeling of teaching skills; and elaboration, activities including skill practice, practice teaching, video tape recording, giving feed back; and for re-creation, teaching creation by the students. The last activities are conclusion and reflection. Third, on the post activity, the instructor should give feedback of the learning process. Evaluation phase in the microteaching model is activity to determine whether the participants have got improvement or not.

There were two stages of the evaluation activities. First, the evaluation process was through teaching test. Second, the activity was obtaining the participants 'opinions by filling a questionnaire sheet to the student teachers. The following was the recommendation model of Micro teaching Based English skills in developing student teachers at English Department of State Islamic University, Imam Bonjol Padang. 


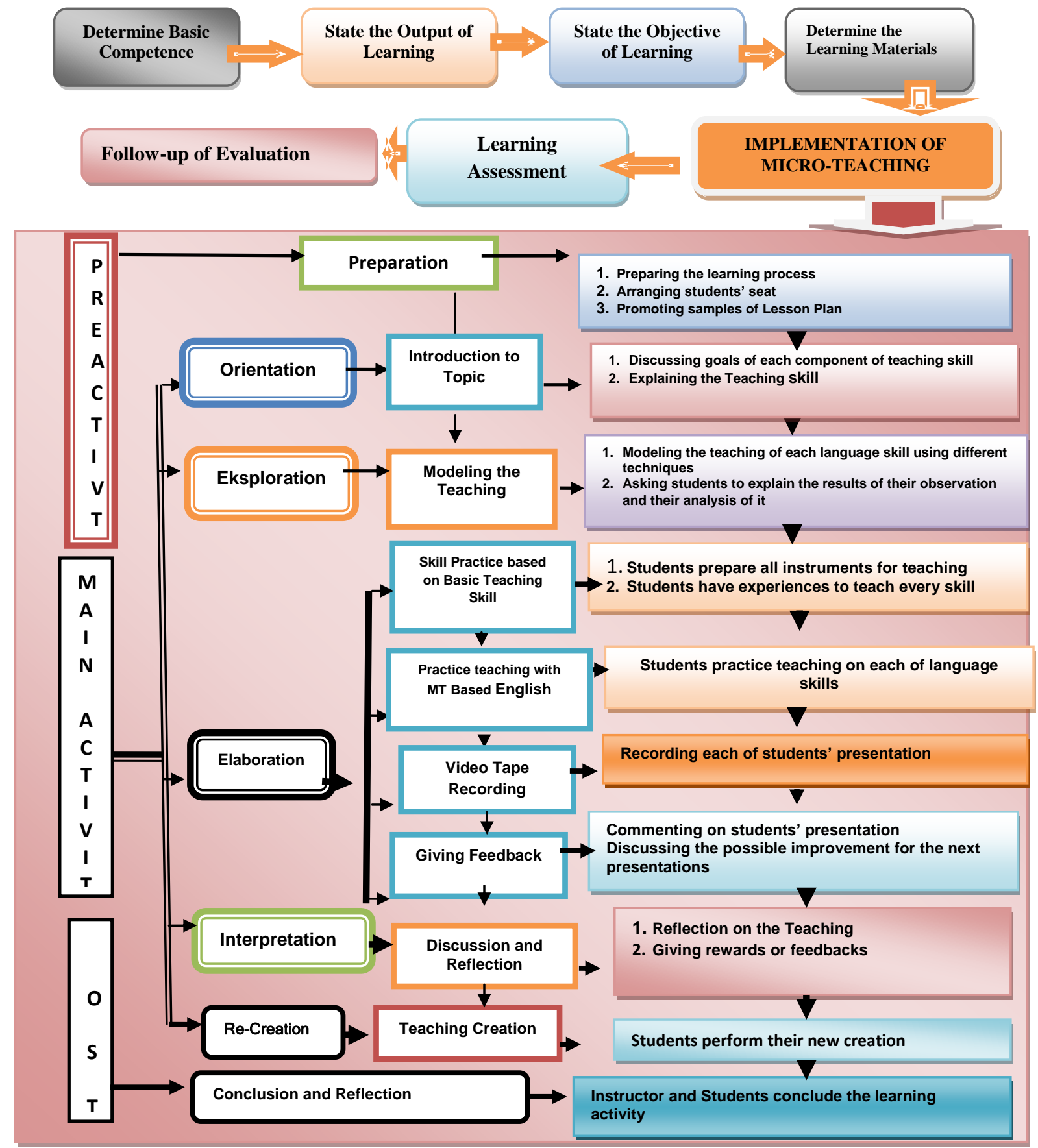

Figure. 1. Recommended Model of Micro-Teaching Based English Skills

The internal consistency of Microteaching based English skills model was very high (94 percents). This model matched with standard of Higher Education Process (96 percents). The systematic arrangement of the components was $96 \%$. The fitness of approach and purpose of Micro-teaching was $96 \%$. The appropriateness of Teaching Steps with Lesson Plan was $92 \%$. The appropriateness of Learning Model with the goals of teaching was $92 \%$. The appropriateness of Learning Model with learning experience was $92 \%$. The appropriateness of Learning Model for real program was $92 \%$. The practicality of learning model of was $96 \%$. The effectiveness of learning model to develop individual students' teaching skill was 96\%. The probability of learning model to be the guidance for the English lecturers to develop active and fun learning was $88 \%$. It can be seen on the following table 1 . 
Table 1. Internal Consistency Model of Micro Teaching Based English Skills

\begin{tabular}{clc}
\hline No & Aspects & Percentage (\%) \\
\hline 1 & Model matched with standard of Higher Education Process & 96 \\
2 & Systematic arrangement of Model & 96 \\
3 & The appropriateness of Model with the purpose of the subject of MT & 96 \\
4 & The Appropriateness of Teaching Steps with Lesson Plan of MT & 92 \\
5 & The Appropriateness of Learning Model of MT with the goals of teaching & 92 \\
6 & The Appropriateness of Learning Model of MT with learning experience & 92 \\
7 & The Appropriateness of Learning Model of MT for real MT program & 92 \\
8 & The Practicality of Learning Model of MT & 96 \\
9 & The Effectiveness of Learning Model of MT to develop Individual students & 96 \\
& teaching skill & 88 \\
& The Probability of Learning Model of MT to be the guidance for the English & $94 \%$ \\
& lecturers to develop active and fun learning \\
\hline
\end{tabular}

Based on the above evidences, it is safe to say that the current learning model of Micro Teaching Based English Skills deserved to be implemented in an effort to develop students' teaching skills in English at State Islamic University.

\section{The Effect of English Skill Based Micro- Teaching Model towards Students' Basic Teaching Skills}

The new developed model has contributed to students' basic skill in teaching as shown in the difference scores obtained from pre and post-test. The finding of the research was found that English Skill Based
Micro teaching Model gave better result on students' teaching basic skills included the design lesson plan, the ability to open, the ability to explain, the ability to use of media, the ability to manage classroom, the ability to share questions, the ability to vary the teaching technique, the ability to handle discussion, and the ability to close the lesson.

Based on the scores obtained, basic teaching skills of the two groups tended to be the same. Both groups had good basic teaching skill before and after the treatment with the means score (75.42 and 75.5 and 80.19 and 80.7). However, each of basic teaching skill components tend to be different as presented in the graph below.

Table 1. Students' Achievement of Basic Teaching Skills (Pre and Post-Test)

\begin{tabular}{|c|c|c|c|c|c|c|c|c|c|}
\hline \multirow[t]{3}{*}{ Description } & & \multicolumn{3}{|c|}{ Pre } & \multicolumn{2}{|c|}{ Post } & \multicolumn{3}{|c|}{ Difference } \\
\hline & & Group & Group & Std. & Group & Group & Std. & Group & Group B \\
\hline & Res & $\mathrm{A}$ & $\mathrm{B}$ & Dev & & & Dev & & \\
\hline Lesson Plan & & 75.8 & 74.6 & 3.97 & 80.5 & 80.8 & 4.02 & $5.7 \%$ & $6.2 \%$ \\
\hline Opening & & 76.2 & 75.5 & 3.87 & 79.4 & 81.5 & 1.96 & $4.2 \%$ & $6.0 \%$ \\
\hline Explaining & & 75.5 & 75.6 & 4.85 & 78.9 & 80.3 & 3.05 & $3.4 \%$ & $4.7 \%$ \\
\hline Reinforcing & 11 & 76.4 & 75.4 & 4.36 & 80.2 & 79.6 & 4.40 & $4.2 \%$ & $4.2 \%$ \\
\hline Media & & 74.5 & 75.4 & 3.88 & 80.6 & 81.8 & 2.24 & $6.1 \%$ & $6.2 \%$ \\
\hline Managing & & 74.0 & 75.4 & 4.05 & 80.2 & 81.3 & 1.66 & $6.2 \%$ & $6.1 \%$ \\
\hline Questioning & & 74.9 & 75.7 & 4.76 & 80.4 & 81.1 & 2.69 & $6.5 \%$ & $4.7 \%$ \\
\hline Varying & & 76.3 & 75.5 & 4.08 & 80.6 & 80.3 & 1.69 & $4.3 \%$ & $5.2 \%$ \\
\hline Discussing & & 76.4 & 76.4 & 4.11 & 79.6 & 80.6 & 1.75 & $3.2 \%$ & $4.2 \%$ \\
\hline Closing & & 74.2 & 75.0 & 4.85 & 81.5 & 80.7 & 4.13 & $7.3 \%$ & $5.7 \%$ \\
\hline Mean score & & 75.42 & 75.45 & 3.97 & 80.19 & 80.7 & 4.02 & $5.71 \%$ & $5.53 \%$ \\
\hline
\end{tabular}

It was clear from the data above that there had been improvement in the students' basic teaching skill.
Each of basic teaching skill components tend to be different as presented in the graph below. 


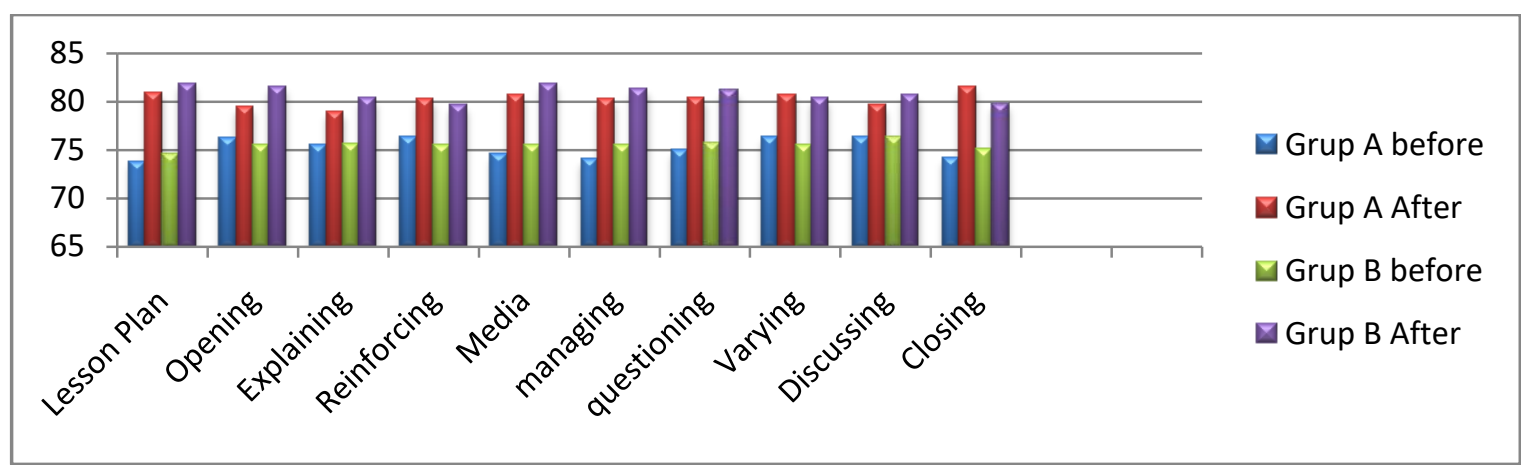

Graph 3. Average score of students' basic teaching skill before and after trying out the New Model (Based on English Skills)

The $\mathrm{T}$-Test results of average gaining score of the two groups (Group A) ( $\bar{X}$ $=3.727)$ and Group B $\quad(\bar{x}=4.909)$ on the significance level .95 . The paired $t$-test for group A was 4.028 and the $p$-value was .00 $(\mathrm{p}<.05)$. In fact, $\mathrm{t}$-count $(4.028)>\mathrm{t}$-tabel (3.169) and $p$-value $(0.00)<\alpha=0.05)$. The paired $\mathrm{t}$-test for group $\mathrm{B}$ was 4.307 and the $p$-value was $.00 \quad(\mathrm{p}<.05)$. In fact, $\mathrm{t}$-count $(4.307)>$ t-tabel (3.169) and p-value was $(0$, $00)<\dot{\alpha}=0,05)$ for Group B. Therefore, there had been significant different between achievements of basic teaching skill by using this model based English skill before and after the tried-out. In other words, model of Micro-teaching Based English skills was effective to improve students' basic teaching skill at English Department State Islamic University.

\section{Dominant Teaching Skills Improved through English Skill Based Micro- Teaching Model}

Model of Micro Teaching Based English Skills generated students' basic teaching skill for all components such as writing lesson plan, use of media, classroom management, and closing the lesson. Based on interviews, students were aided in mastering basic teaching skills and components.

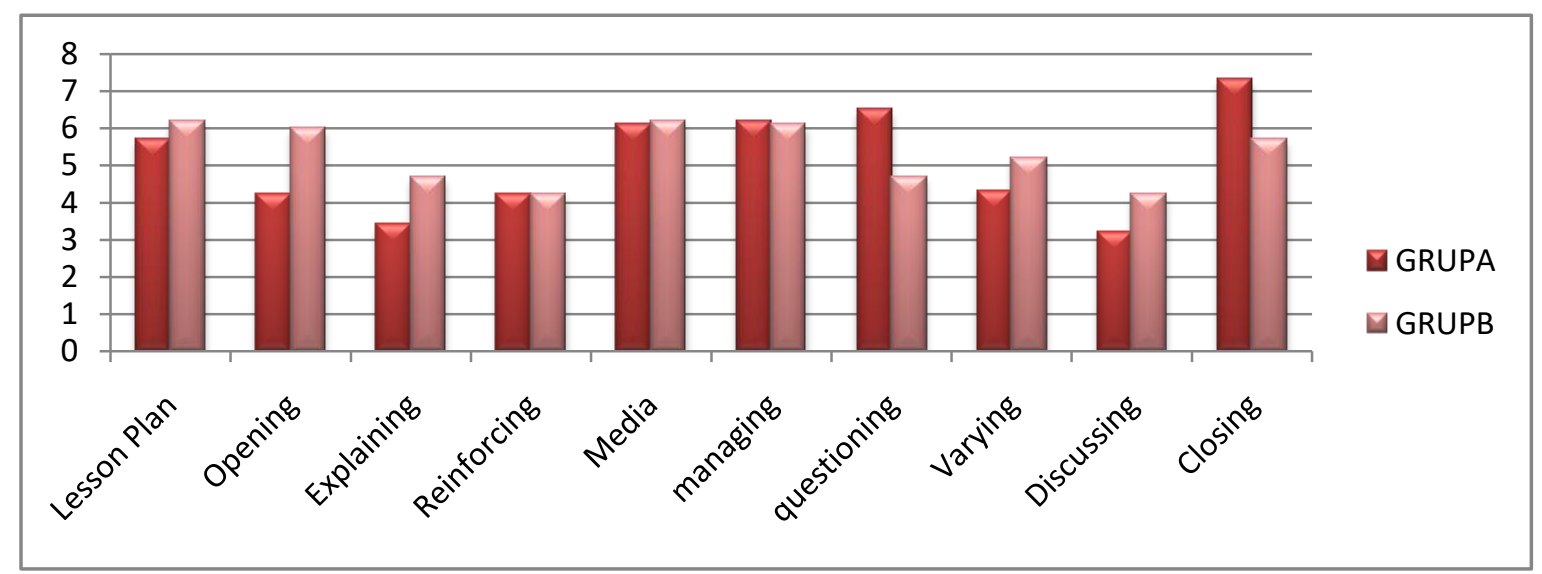

Graph 3. Dominant Basic Teaching Skills Improved through Model of Micro-Teaching Based English Skill

The Effect of English Skill Based MicroTeaching Model towards Students' English Teaching Skills

Students' teaching skills on listening, speaking, reading, and writing were based on the indicators such as accuracy, appropriateness, and fluency, and they were tabulated and analyzed through SPSS 17.0. It was found that both groups had the same English teaching skills (74.1 and 74.6). However, it was found that teaching skills of listening and reading were quite low. Students' English teaching skills for the two groups improved after the treatment (triedout), in which Group A was 80.97 and Group B was 81.25 as depicted in graph2. 
Tabel 2. Students' Teaching Skills (Pre test dan Post test)

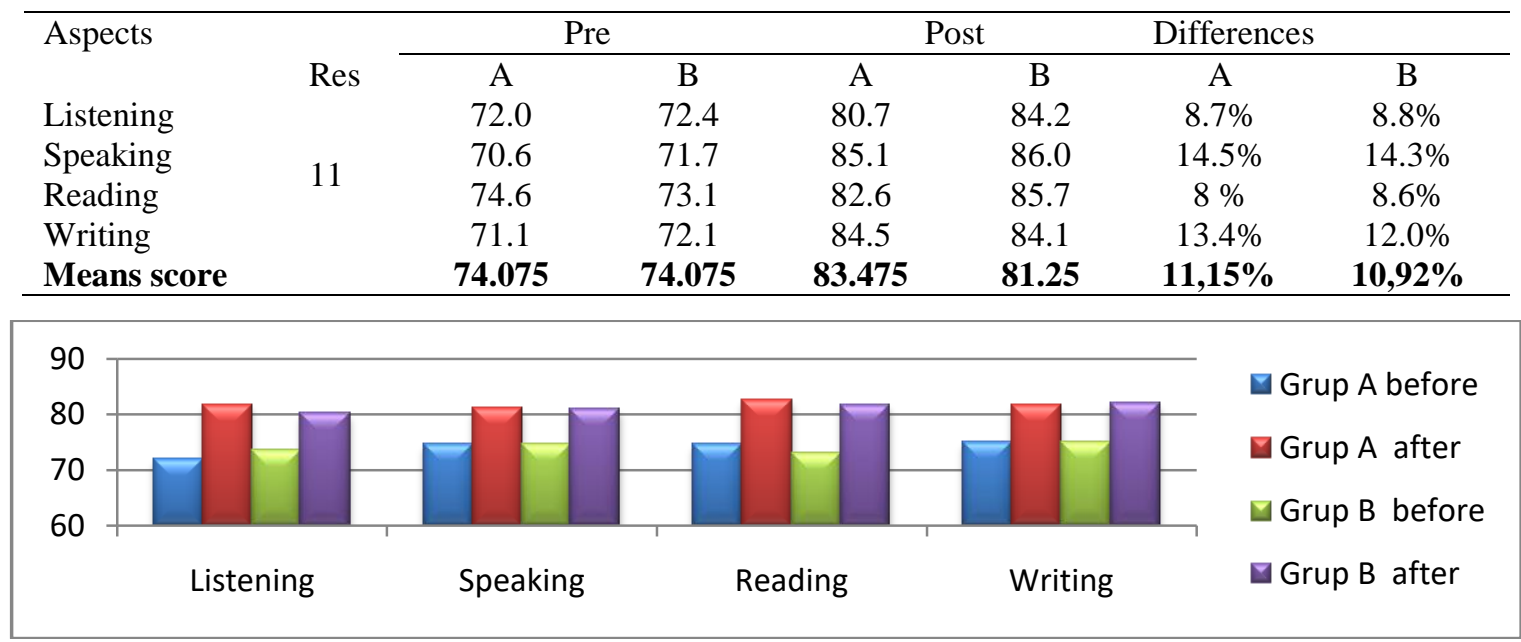

Graph 2. Average score of students' English Teaching Skill in the Pre test and Post-test.

The T-Test results of average gaining score of the two groups (Group A) ( $\bar{X}$ $=6.818)$ and Group B $(\bar{x}=6.909))$ on the significance level .95 . The paired $\mathrm{t}$-test for group A was 8.117 and the $p$-value was .00 $(\mathrm{p}<.05)$. In fact, $\mathrm{t}$-count $(8.1168)>\mathrm{t}$-tabel (3.169) and p-value $(0.00)<\alpha=0.05)$. The paired $\mathrm{t}$-test for group B was 6.645 and the $p$-value was $.00 \quad(\mathrm{p}<.05$. In fact, $\mathrm{t}$-count $(6.645)>\mathrm{t}$-tabel (3.169) and p-value was $(0$, $00)<\dot{\alpha}=0,05)$ for Group B.

\section{Dominant English Teaching Skills Improved through English Skill Based Micro-Teaching Model}

The post-test results showed that the new model improved students' basic teaching skill in listening, speaking, reading, and writing. The post-test results showed that the new model improved students' English teaching skills in listening, speaking, reading, and writing. The average improvements of the two groups were $8.7 \%$ and $14.5 \%$ (for listening and speaking) and 8.8 and $13.4 \%$ for reading and writing for group A. $8.8 \%$ and $14.3 \%$ for (listening and speaking) and $8.6 \%$ and $12.0 \%$ for (reading and writing) for group B. it can be concluded that teaching speaking and writing skills were better improved for both two groups. The result of interviews with the students supported the findings that they were helped in teaching especially in mastering the topic of the lesson. Almost all students were able to apply various techniques in the classroom

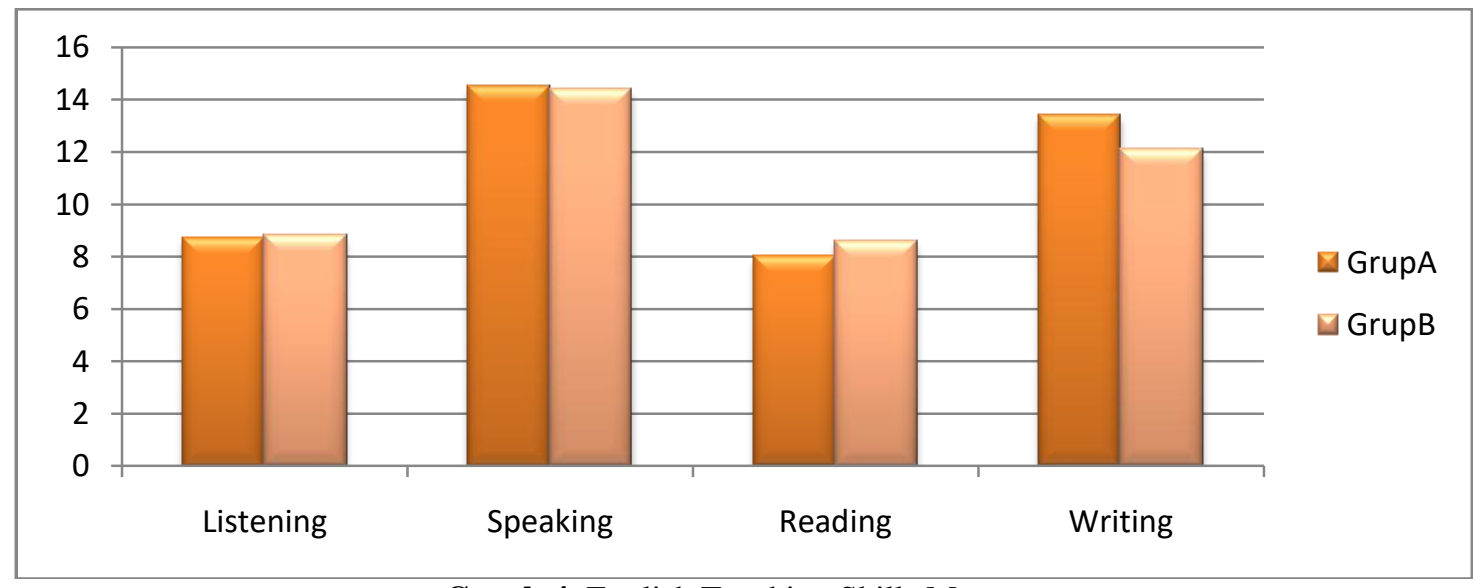

Graph 4. English Teaching Skills Mastery

Students' most dominant skills in English teaching were speaking and writing. However, the four language skills were better than previously taught through model of Micro-teaching Based English Skills. Therefore, this model deserved to apply as 
one of the alternative models in developing students' English Teaching Skills in the future.

\section{RESULT AND DISCUSSION}

The art of teaching does not merely involve a simple transfer of knowledge from one to other. Instead, it is a complex process that facilitates and influences the process of learning. Quality of a teacher is estimated on how much the students understand from his/her teaching (Remesh, 2013).The design of this learning model has incorporated primary components for learning such as: basic competence, learning outcomes, learning goals, materials, classroom activities, and evaluation (Joice, Weil \& Showers (1992).

English skill based microteaching model has been designed to help student teachers to be better in mastering English teaching skills including teaching listening, speaking, reading and writing skills. The main syntax of this model consists of preteaching or introduction, main teaching, and post teaching. First, the activities on the preliminary activities include take attendance, build participants' attention, motivate participants and, greet them, provide guidance learning, and give them pre test. Before conducting the training process, the facilitators do setting arrangement. Setting the seat in teaching process is conducted in order to make the students more active and more joy full (Harmer, 2001; McLeod, Fisher, \& Hoover, 2003). Second, there are five activities for the main' teaching activities including orientation, exploration, elaboration, interpretation, and re-creation. In the Closing activity, Instructor is supposed to maintain students; positive achievement by giving rewards or other motivation. Evaluation stage in the Micro Teaching process is directed to determine whether or not students have made some improvements.

Based on the statistical analysis of hypothesis testing, it is found that the students' mean scores post test is higher than pre test for both two groups. English Skill
Based Micro teaching model had better result on students' basic teaching skill on preparing lesson plan, opening teaching activity, explaining the lesson, the using media, managing classroom, questioning technique, varying teaching technique, handling discussion, and closing teaching activity. It is in line with Ping' Idea in his research (Ping, 2013). He stated that micro-teaching provides a powerful and constructive setting for the development of such specific teaching skills. Instructors models and facilitate students through the following things such as orient the materials, check students' current teaching skill, model the teaching, discuss, encourage students to have high self confidence in teaching, guide students individually to teach and master the components, observe each students' presentation (teaching), give feedbacks, do a re-teaching, and do the evaluation

The results of this model showed the improvement of students' basic teaching skills and their English skills in each component. There have been significant different between achievements of English teaching skill by using this model before and after the treatment. For basic teaching skills, the student teachers are able to prepare the lesson plan. They can stimulate the students in pre teaching activity. In addition, they are able to use various teaching techniques with the appropriate English skills. They are able to use appropriate media in teaching English skills. While for teaching English skills, they have been able to teach listening, speaking reading and writing skills communicatively. They are able to motivate students to speak and to write with various teaching techniques.

Microteaching model helps not only in developing skills of the novice teachers but also assists in comparing the effectiveness of variation of one microteaching with another. Microteaching has the ability to enhance the skills of problem solving, critical thinking, questioning, and reflective thinking. It improves learning by realistic applications. The other key benefits of this technique included the following: Transformation of difficult topics into learnable units, usage of 
advanced organizers, integration of the lecture with applications on topics, and usage of proper questions and pauses.

Teaching English to small group allows the student teachers to focus their attention in mastering specific English technique. Other positive aspect of this model was that students were very enthusiasm. Besides, learning atmosphere under this model gave fun and secure to students' learning because of well interactions between instructors and students. Such a good relationship should be created to form a sense of democracy, interactive, but not instructive (Prayitno, 2008). This finding also was confirmed by Fosmire and Alexius (2000), that learning would be more effective provided that students had been involved more actively in their groups. Through this way, students develop their own potentialities without being shy to practice teaching cooperatively, asking and answering questions, and discussing.

Recent research findings (Brookhart, 2010; Votlz et al, 2010;Goetz, 2011; Milanoski, 2011) confirm that microteaching is effective in helping pre service teacher to improve multiple frames of references and observation skills. This finding supported the previous studies that microteaching process developed components of teaching, but not for every basic teaching skill (Natalia, 2013; Oktavia, 2014; Najjah, 2014). Thus, it is concluded that English Skill Based Micro Teaching Model deserves to be an alternative learning model of micro-teaching at English classroom for student teachers.

\section{CONCLUSION AND RECOMMENDATION}

The significance differences between students' basic teaching skill (before and after the implementation of Microteaching Based English skill indicated that this model has successfully moved on the tracks by guiding students' learning based on their capacity. Although students have been provided with ways of how to arrange the lesson plan through Instructional Design subject, actual use or implementation of such a scenario was much more beneficial for the students' actual practice. Opening the lesson which is identical with getting attention - ice-breaking, or relating students' background knowledge have been developing in the model through multiple perspectives and in accordance with the pedagogy and linguistics. Theoretical subject on Instructional Media that students learnt prior to Micro-teaching subject proved to be inconsistent with the output of the subject. This implied that instructor of media should re-examine her goal, as well as method, and evaluation.

The current model has particularly demonstrated how classroom should be managed so as to reach conductive learning. Basic teaching skills were developed step by step through multiple approaches and techniques, methods, whether individually, or in groups /peers. The results of implementation also have implications for some fundamental changes for individual students in developing competence and teaching skills in English. Therefore, this model needs to be implemented intensively in the future in the Microteaching class to find strengths and weaknesses of this model so that it will continue to be developed in order to develop the competencies and skills of future English teacher candidates at UIN Imam Bonjol Padang at English Language Department.

Based on the discussion and conclusions above, it is suggested that the teaching skills of prospective English language teachers must be taught intensively so that the skills and competencies of teaching in the field are more qualified and competitive. Therefore, the English skillbased Microteaching model is feasible to be implemented by English Microteaching lecturers. To see and find the influence of this model deeper, further research needs to be done in the form of action research. This aims are to make the component of teaching skills better improved. To test the feasibility of this model, it is necessary to implement it at the English Language Department outside the 
English department of Islamic University of Imam Bonjol Padang.

\section{REFERENCES}

Arikunto, S (1993). Manajemen Pengajaran

Secara Manusia. Jakarta: Rineka Cipta.

Arends, Richard. (2008). Learning to Teach, Avenue of the Americas New York, NY 10020: McGraw-Hill Companies, Inc 1221.

Atwi Suparman. M. (2001). Desain Instruksional. Pusat Antar Universitas untuk Peningkatan dan Pengembangan Aktivitas Instruksional. Jakarta: Direktorat Jendral Pendidikan Tinggi Depdiknas.

Asril, Zainal. (2010). Micro-Teaching. Jakarta: Rajawali Pers.

Anson J, Rodrigues S, Wilson G. 2003. Mirrors, Reflections and Refractions: the Contribution of Microteaching to Reflective Practice. Eur J Teach Educ.26:189-99.

Allen DW, Wang W. Beijing: Xinhua Press; 1996. Microteaching.

Besral, Darmayenti. (2016). Upaya peningkatan Pembelajaran Microteaching di Jurusan tadris Bahasa Inggris IAIN Imam Bonjol Padang. Fakultas Tarbiyah 2016.

Bell ND. (2007). Microteaching, What is it that is going on here? Linguist educ.; 18:24-40.

Borg, Walter, R \& Gall, Meredith, D,. (2007). Educational Research: An Introduction. New York: Longman Inc.

Brookhart, S., 2010. How to assess higherorder thinking skills in your classroom. Alexandria, VA: Association of Supervision and Curriculum Development.

Brown, H. D. (1994). Teaching by Principles: Interactive Language Teaching
Methodology. New York: Prentice Hall Regents.

Brown, H. D \& Priyanvada Abeywickrama. (2010). Language Assesment: Principle and Classroom Practices. New York: Pearson Education Inc.

Burns, A. \& Joyce, H. (1997).Focus on Speaking. Sydney: National Center for English Language Teaching and Research.

Chen Q, Zeng F, Yang Z. (2010). Study on the effects of multimedia monitoring system in medical teacher's microteaching training. Comput Inf Sci.;3:241-3.

Darmayenti, Besral.( 2017). Development of Microteaching model for English departement UIN Imam Bonjol Padang. Unpublished research. Funded by DIPA UIN Imam Bojnol Padang 2017.

Deniz S. (2011). Implications of Training Student Teachers of Pre-schooling through Micro-Teaching Activities for a Classroom with Mentally-disabled Students. Educ Res Rev.;6:560-9.

Educational Ministry Decree No 16 Year 2007 tAcademic and Teacher Qualification. Jakarta: National Education Department.

Educational Law No 14 (2005). Jakarta: Sinar Grafika.

Fraenkel. Jack R. \& Norman E.Wallen. (1990). How to Design and Evaluate Research. New York: McGraw-Hill Publishing Company.

Fernadez, M. 2005. Learning through Microteaching Lesson Study in Teacher Preparation. Action in Teacher Education Journal, Volume 26, 2005 - Issue 4.

Goetz, T., 2011. The feedback loop: how technology has turned an age-old concept into an exciting new strategy 
for changing human behavior. Wired, 3(19), 126-162.

Government Regulation No: 19 Year 2005. Jakarta: National Education Department.

Gan, Z. (2013). Learning to teach English language in the practicum. What challenges do non-native ESL teachers face? Australian journal of Teacher Education. vol 38,3.

Genc, B. \& Buyukkarci, K. (2013). An assessment of pre-service language teachers' practicum observation forms: descriptive observation vs critical observation. Educational research E Journal, 2 (2), 83-91

Haigh, M. et.al. (2015). Practicum's contribution to students' learning to teach.

Hamaidi et al (2014). Student-teacher perspectives of practicum practices and challenges. European scientific journal. vol 10, No 13.

Harmer, J. 2003. The Practice of English Language Teaching (3 edition). London:Longman.

---.1998. How to Teach English. London:Longman

Ismail, Sadiq Abdulwahed Ahmed. (2011) Journal LanguageTeaching Res1043-51

Jacobs. L. Holly. 1981. Testing ESL Composition: A Practical Approach. London

Joyce, B., Weil, M. \& Calhoun, E. (2000). Models of Teaching Sixth Edition. Boston: Allyn and Bacon.

Klinzing, H. G., \& Folden. R. E. (1991). The development of the microteaching movement in Europe. ERIC Documentation Reproduction Service No. ED 352341.

Liston, D., Whitcomb, J., \& Borko, H. (2006). Too little or too much: Teacher preparation and the first years of teaching. Journal of Teacher Education. 57(4), 351-358.

Law of Educational System No 20. (2003). National Education. Jakarta: BP.Cipta Jaya.

Milanowski, A., 2011. Strategic measures of teacher performance. Phi Delta Kappan 92(7), 19-25.

Mulyasa, E., (2003). Kurikulum Berbasis Kompetensi: Konsep, Karakteristik, dan Implementasi. Bandung: PT Remaja Rosdakarya.

Majid, Abdul. (2005). Perencanaan Pembelajaran: Mengembangkan Standar Kompetensi Guru. Bandung: PT Remaja Rosdakarya.

Mergler A. G. \& D Tangen. (2010). Using microteaching to enhance teacher efficacy in pre-service teachers. Teaching Education Journal, Volume 21, 2010 - Issue 2

Meredith D. Gall, Joyce P. Gall, Walter R. Borg. (2007). Educational Research: An Introduction. Eight Edition. Boston: Pearson/Allyn Bacon.

Najjah, I.s (2014). Pengaruh Nilai Micro Teaching terhadap Kemampuan Mengajar Praktek Pengalaman Lapangan Mahasiswa S1 Program Studi Tadris Biologi Angkatan 2010 Semarang. Unpublished Thesis.

Nasution, S. (2008). Berbagai Pendekatan dalam Proses Belajar Mengajar. Jakarta: Bumi Aksara.

Natalia S, (2013). Pengaruh Micro Teaching dan Bimbingan Guru Pamong terhadap Kemampuan Mengajar Mahasiswa PPL FKIP UNS Surakarta Jupe UNS, Vol 1, No 1, Hal 1 s/d 11.

Omar, Mohd Zulkifli. (2014). The Need for In-Service Training for Teachers and It' $s$ Effectiveness in School. In International Journal for Innovation 
Education and Research. Vol. 2 No. 11 (page 1-9).

Osamwonyy, E.F. (2016). In-Service Education of Teachers: Overview, Problems and the Way Forward. In Journal of Education and Practice. Vol. 7, No.26 (p. 83-87).

Ping, W. 2013. Micro-teaching: a powerful tool to embedding the English Teacher certification testing in the development of English Teaching methodologies. International Journal of English Language and Literature Studies Volume 2(3):163-175.

Paintal I. 1980. Micro-teaching-A Hand Book for Teachers. University New Delhi: Oxford Press.

Prayitno. (2008). Dasar Teori dan Praksis Pendidikan. UNP Press. Padang.

Prawiradilaga, Dewi Salma.(2008). Prinsip Desain Pembelajaran. Jakarta: Universitas Negeri Jakarta.

Remesh Ambili, (2013) Microteaching, an efficient technique for learning effective teaching. Journal of research in medical sciences. Vol 10 Issue. 2

Richey, R.C; Klein, James D \& Nelson, W.A (2007). Develomental Research: Studies of Instructional Design and Development. Handbook of Research for Educational Communication and Technology. New York, MacMillan Simon \& Schuster.

Richard, F \& Anita Liu. (2008). Research Method for Construction. USA. B;lackwell Publishing Ltd.

Sanjaya, Wina. (2006). Strategi Pembelajaran Berorientasi Standar Proses Pendidikan. Jakarta: Kencana Prenada Media Group.
Sagala S. 2009). Kemampuan Professional Guru Dan Tenaga Kependidikan. (Bandung: Alfabeta,

Sanapiah Faisal (1990). Penelitian Kulaitatif Dasar Dasar dan aplikasi. Malang YA3.

Seels, Barbara B dan Richey, Rita.C. (1994). Instrucional Tecnology. Wasington.

Soekamto, Toeti dan Udin, S.W. (1997). Teori Belajar dan Model -model Pembelajaran. Jakarta.

Sugiyono. (2010) Metode Penelitian Pendidikan: Pendekatan Kuantitatif, Kualitatif, dan R\&D. Bandung:Alfabeta.

Susan Stainback. (1988). Understanding \& Conducting Qualitative Research. Kendal/Hunt Publishing Company Dubuque, Iowa.

Starkey, L. and Rawlins, P. (2012). Student Teacher Learning during practicum experience, Tean Journal 4 (1). Available at: http://bit/ly15VJ5s.

Tuli, F. and File, G. (2009). Practicum experience in teacher education. Ethiopian Jourrnal of Education and Science. 5 (1). 107-116.

Ulla, Mark B. (2016). Pre-service Teacher Training Programs in the Philippines: The Student-teachers Practicum Teaching Experience. In EFL JOURNAL, Volume 1 (3).p236-250.

Widdowson; H.G.(1978). Teaching Language as Communication. Oxford:Oxford University Press.

Yusoh, et.al (2014). Student Teacher Perception Toward Teaching Practicum Program. International Journal for Innovation Education and Research. 210, 2014. 